\title{
Sequence of Ossification in the Skeleton of Growing and Metamorphosing Tadpoles of Rana pipiens '
}

\author{
NORMAN E. KEMP AND JUDITH A. HOYT \\ Department of Zoology, The University of Michigan, \\ Ann Arbor, Michigan
}

\begin{abstract}
The order of ossification of bones in the skeleton of Rana pipiens during larval growth and metamorphosis has been determined from observations on specimens fixed in $70 \%$ alcohol and stained with alizarin red $S$. The axial skeleton ossifies in a generally cephalo-caudal sequence, beginning with the parasphenoid bone at Taylor-Kollros stages IV-IX, followed by vertebrae (V-IX) and then the urostyle (IX-XIV). Exoccipitals (VII-IX), frontoparietals (XI-XII) and prootics (XIII-XVII) are additional cranial bones which successively ossify before metamorphosis. With the onset of metamorphosis at stage XVIII jawbones and rostral bones of the skull ossify in the following succession: premaxilla, maxilla, septomaxilla, nasal, dentary, angular, squamosal, pterygoid, prevomer, mentomeckelian, quadratojugal, palatine, columella, posteromedial process of "hyoid." The sphenethmoid does not ossify until after metamorphosis.

Ossification of limbbones begins with the femur or humerus at stages X-XII and progresses proximo-distally to the phalanges by stages XIII-XV. Carpals, however, do not ossify until stage XXV or after metamorphosis. The ilium of the pelvic girdle begins to ossify at stages X-XII, but the ischium is delayed until stages XX-XXIII. Scapula and coracoid of the pectoral girdle undergo initial ossification at stages XIIXIV, suprascapula and clavicle at stages XIII-XV. The sternum does not begin to ossify until stage XXIV. The possible role of thyroid hormones in stimulating osteogenesis is dicussed.
\end{abstract}

Bone is a vertebrate tissue which develops after larval differentiation of connective tissue and cartilage. Once osteogenesis commences, bones ossify in a sequence which is characteristic for the species. While studying the influence of thyroxine on development of limb and skull bones in Rana pipiens (Kemp and Hoyt, ' $65 \mathrm{a}, \mathrm{b}, \mathrm{c}$ ), we became aware of the need for a reliable reference on the chronology of ossification in this species. This paper is designed to provide such a reference by correlating skeletal development with the developmental stages of Taylor and Kollros (46). We also wish to discuss the general problem of sequential morphogenesis of bones.

Skeletal development in anuran amphibians has been treated extensively in publications by Parker (1871, 1876, 1881), Gaupp (1896, '06), Kingsley ('25), Erdmann ('33), DeBeer ('37) and Goodrich ('58). Most of the published work on development of the frog skeleton has dealt with the European species Rana fusca (synonym temporaria) or Rana esculenta, although Parker (1881) has compared developing skulls of several anurans, including Rana pipiens. Erdmann's ('33) careful study of the order of ossification of skeletal elements both in Triton vulgaris and in Rana temporaria provided the basis for DeBeer's ('37) account of the sequence of osteocranial differentiation in Rana. Sequential ossification of skull bones has also been reported for two hylid species, Pseudacris nigrita triseriata (Stokely and List, '54) and Hyla septentrionalis (Trueb, '66).

Ossification of the skeleton of Rana pipiens begins in the parasphenoid bone at stages IV-IX (Kemp and Hoyt, '65a,b) and progresses cephalo-caudally along the vertebral column. Limb bones ossify in proximo-distal sequence, starting with the femur (Kemp and Hoyt, '65c) or the humerus at stages X-XII. Jawbones develop in medio-lateral sequence during

\footnotetext{
1 Supported by research grants from the National Science Foundation (GB 4317 ) and the U. S. Public Science Foundation (GB 4317)
Health Service (GM 05867-10).
} 
metamorphosis, starting with the premaxilla at stage XVIII (Kemp and Hoyt, '65b).

Thyroxine administered to amphibian larvae induces accelerated differentiation of bones of the skull, vertebral column and limbs (Fox and Irving, '50; Kaltenbach, '53; Kuhn and Hammer, '56; Kemp and Hoyt, '65c). Tadpoles of Rana pipiens treated with thyroxine at stages IV-IX, before osteogenesis had begun in the limbs, underwent precocious ossification of the premaxilla (Kemp and Hoyt, '65b). Thyroid hormones promote maturative changes in explanted limb bones of chicks or mice (Fell and Mellanby, '55, '56; Lengemann, '62; Lawson, '63; Gaillard, '63). An osteogenic stimulatory factor, possibly mucoprotein, has been extracted from bone, muscle, bladder and cartilage (Moss, '60). The factors which regulate normal sequential osteogenesis have yet to be identified.

\section{MATERIAL AND METHODS}

Embryos of Rana pipiens were obtained in the laboratory by artificial ovulation and fertilization. Adults used for eggs and sperm were purchased from E. G. Steinhilber, Oshkosh, Wisconsin. Larvae were reared in $11^{\prime \prime} \times 16^{\prime \prime}$ enamel pans holding about an inch of water previously conditioned by aerating tap water for at least 12 hours. Animals were fed boiled spinach or lettuce three times weekly following a change of water. Before fixation they were staged according to the criteria of Taylor and Kollros ('46).

Two-hundred-seventy-seven laboratoryreared specimens plus five metamorphosing tadpoles of Rana pipiens collected from a pond near Ann Arbor, Michigan, were fixed in $70 \%$ alcohol for one week or more, then stained with alizarin red $\mathrm{S}$ and stored in a 1:1 mixture of glycerine and ethanol according to Mayorga's ('65) technique.

Specimens were photographed with an Exacta reflex camera, utilizing both reflected and transmitted light. Dorsal, lateral and ventral views were photographed, and drawings were made by comparing the direct microscopic image with the photographic image. We have adopted
DeBeer's ('37) anglicized terminology for skull bones.

\section{OBSERVATIONS \\ Appendicular skeleton}

Ossification begins in the proximal leg bones by stages X-XII (table 1 ) and progresses to include hindlimb phalanges by stages XIII-XV. We have found no evidence that the calcar of the prehallux of the foot mineralizes before the end of metamorphosis. Bones of the pelvic girdle ossify in dorso-ventral sequence, beginning with the ilium at stages X-XII. The humerus begins to ossify at stages $\mathrm{X}-\mathrm{XII}$, but more distal arm bones ossify somewhat later than comparable bones of the hindlimb. Phalanges of the forelimb are ossifying by stages XIV-XVI. Carpals, however, are delayed in their ossification until stage XXV or later. Bones of the pectoral girdle begin ossification at stages XII-XV.

Observations on individual bones are recorded below. The range of stages for onset of ossification, shown in parentheses after the name of each bone, indicates the earliest stage of onset and the stage when $100 \%$ of examined specimens had begun ossification.

\section{Hindlimb}

Femur (X-XII). Ossification of the femur begins periosteally in the region of the diaphysis of its cartilaginous rudiment. Osteoblasts differentiate from inner perichondrial cells and secrete the constituents of the osteoid matrix which is deposited around the cartilage (Kemp and Hoyt, '65c). The matrix begins to mineralize by deposition of hydroxyapatite crystallites within collagen fibrils (Glimcher, ' 60 ); but the roles of collagen and the proteinpoly. saccharides of ground substance in promoting mineralization are not clear (Weidmann, '63). Epiphyses of the femur and other limb bones remain cartilaginous in adults of Ranidae, although the epiphyseal cartilage may be partly calcified (Gaupp, 1896; McEwen, '57).

Tibiofibula (X-XII). Tibia and fibula commence ossification as separate bones around their individual cartilaginous primordia. At about stage XIX the two bones begin to fuse. Because of their length, 


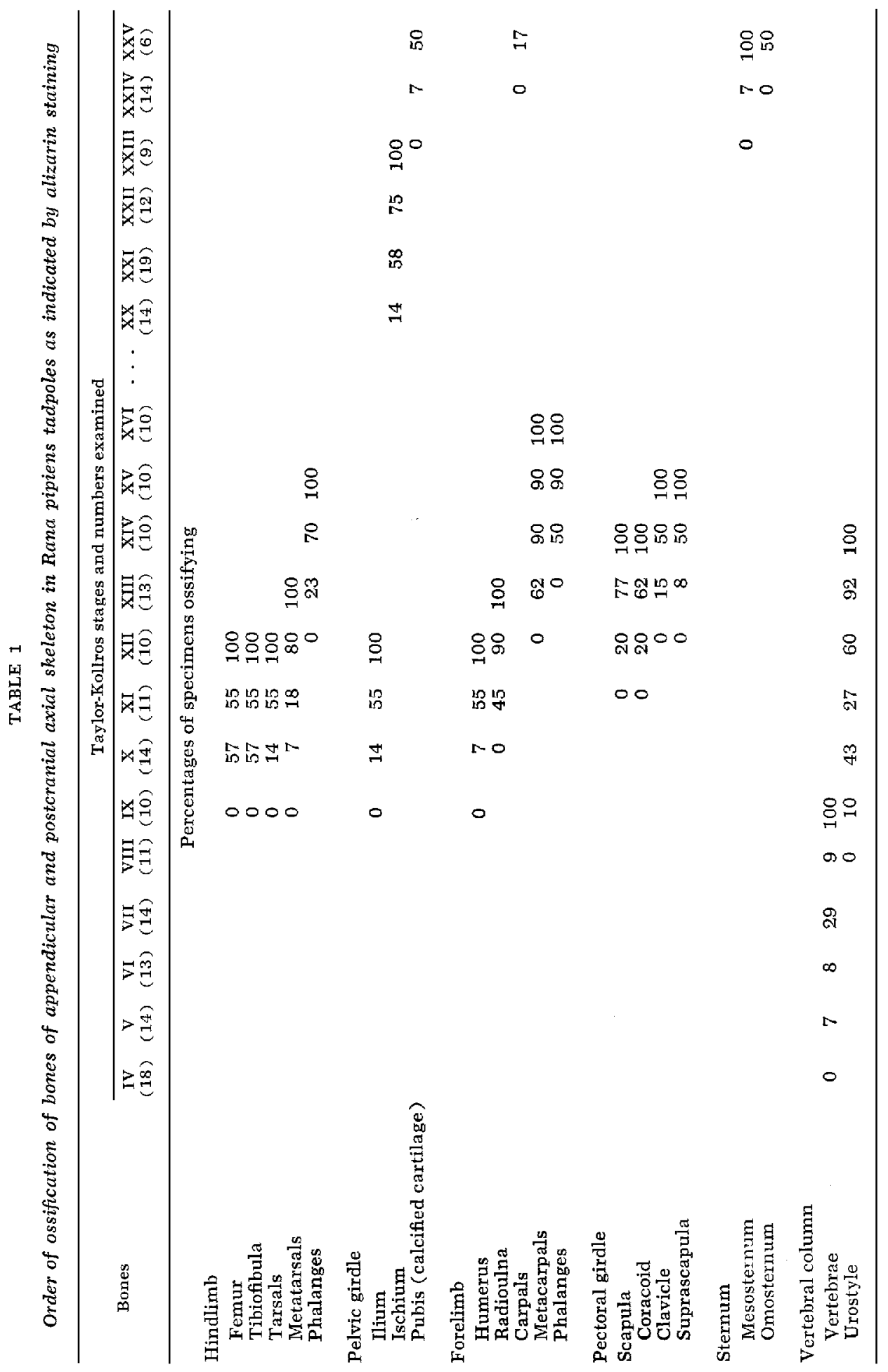


they undergo more extensive modification during fusion than do their shorter forelimb counterparts, the radius and ulna. As a prelude to fusion, calcification apparently is reduced in the apposing sides of tibia and fibula until about half of each shaft no longer stains positively with alizarin. The free edges of the remaining mineralized half-shafts then become united by mineralized bridges, beginning at stages XVIII to XX. In our specimens $45 \%$ showed confluent mineral at stage XVIII, $92 \%$ at stage XIX and $100 \%$ at stage XX.

Tarsals (X-XII). These bones begin to ossify together with or shortly after the femur and tibifibula.

Metatarsals (X-XIII). These elements tend to lag slightly behind the tarsals in onset of ossification.

Phalanges of Hindlimb (XIII-XV). Bones of the digits begin to ossify as digital joints and proximal toe pads are forming.

\section{Pelvic girdle}

Ilium (X-XII). This bone like the tarsals begins to ossify together with or shortly after the femur and tibiofibula.

Ischium (XX-XXIII). Ossification of this bone begins during metamorphosis after protrusion of forelimbs and obvious changes in the external appearance of the jaws. The ischium is unpaired and contributes to the acetabulum on either side (Gaupp, 1896).

Pubis (XXIV-XXV). This portion of the pelvic girdle does not ossify, but its cartilage becomes calcified (Gaupp 1896; Holmes, '12). Our results show that calcification had begun in $50 \%$ of specimens examined at stage XXV.

\section{Forelimb}

Humerus (X-XII). After first developing as a cylindrical collar of periosteal bone, the humerus becomes modified by development of the crista medialis along its proximal half. This bony ridge was present in $60 \%$ of animals examined at stage XVII and in 100\% at stage XX.

Radioulna (XI-XIII). Radius and ulna begin to ossify independently, but fusion begins about stage XVII. There is little remodeling before fusion, in contrast to the demineralization which precedes fusion of tibia and fibula. At stage XVIII $60 \%$ of our specimens showed confluence of apposed mineralized surfaces of radius and ulna. The ratio increased to $85 \%$ at stage XVIII and to $100 \%$ at stage XIX.

Metacarpals (XIII-XVI). These bones lag two or three stages bchind their counterparts, the metatarsals of the hindlimb.

Phalanges of forelimb (XIII-XV). It is noteworthy that phalanges begin to ossify at about the same time in forelimb and hindlimb.

Carpals (XXV). Ossification of these bones is generally delayed until after metamorphosis. Only one of six specimens showed mineralization by the end of metamorphosis.

\section{Pectoral girdle}

Scapula (XII-XIV). Ossification begins about two stages later than in the humerus or the upper bones of the hindlimb.

Coracoid (XII-XIV). Ossification of coracoid and scapula proceed on approximately the same schedule.

Suprascapula (XIII-XV). This bone begins to ossify about one stage later than the scapula and coracoid. It is only partly ossified in adult frogs (Gaupp, 1896).

Clavicle (XIII-XV). Ossification proceeds simultaneously in clavicle and suprascapula.

\section{Postcranial axial skeleton}

For convenience axial bones of the vertebral column and sternum are considered separately from those of the skull. It will be observed by reference to table 1 that the vertebrae and urostyle begin to ossify well before metamorphosis, whereas the sternum does not commence ossification until late in metamorphosis.

\section{Vertebral column}

Vertebrae (V-IX). As is typical of most frogs (Gaupp, 1896; Villee, Walker and Smith, '68), Rana pipiens has nine vertebrae. Mineralization begins in both centra and neural arches almost concurrently. The following description applies to the typical vertebrae, numbers 2 to 7 in the series of 9 . Details are somewhat modified in the first, eighth and ninth vertebrae. 
Neural arches develop bilaterally from three parts: a vertical, lateral portion; a caudally directed dorsal portion; and a transverse process. First to appear is the lateral portion, which is joined somewhat later by the dorsal portion. Transverse processes grow out from the region of juncture of the other two components. Although mineralization begins in a cephalo-caudal sequence, fusion of the paired dorsal components of the neural arches proceeds caudo-cephalically. Completion of the neural arches does not begin until toward the end of metamorphosis, and the process continues after metamorphosis.

Rudiments of the centra appear initially as saddle-shaped patches of bone on the dorsal half of the notochord. Lateral components of the neural arches abut ventrally against the centra. Mineralization gradually encircles the notochord during growth of the tadpole but remains perinotochordal until after metamorphosis.

Urostyle (IX-XIV). Stokely and List (55) have reported that the urostyle in Pseudacris nigrita triseriata develops from dorsal and ventral rudiments which are fused in the adult. In Rana pipiens this bone develops from two pairs of dorsal rudiments in line with the vertical neural arches and from an unsegmented ventral portion. The anterior pair of dorsal rudiments resemble the paired primordia of a neural arch at an early stage when only lateral components are mineralized. The posterior pair of dorsal rudiments show vestiges of segmentation toward their anterior ends. Both the anterior and posterior dorsal rudiments extend around the dorsolateral surfaces of the notochord and fuse ventro-laterally. The ventral component of the urostyle, called the hypochord by Stokely and List ('55), is an unpaired, unsegmented, trough-shaped bone which follows the ventral contour of the notochord. As the notochord in the tail is resorbed during metamorphosis, dorsal and ventral components of the urostyle are brought into apposition. They do not fuse, however, until after metamorphosis.

\section{Sternum}

Mesosternum (XXIV-XXV). Ossification of the posterior sternal bone, the meso- sternum (Villee, Walker and Smith, '68) or pars ossea of the sternum (Gaupp, 1896), begins toward the end of metamorphosis. The terminal xiphisternum or pars cartilago of the sternum remains cartilaginous in the adult.

Omosternum (XXV). The anterior sternal bone, the omosternum (Villee, Walker and Smith, '68) or pars ossea of the episternum (Gaupp, 1896), had begun to ossify in $50 \%$ of specimens we examined at stage XXV. The episternum or pars cartilago of the episternum remains cartilaginous in the adult.

\section{Skull}

The skull includes bones of the cranium, consisting of brain case and attached sense capsules, and also those of the visceral skeleton (Holmes, '12; Kingsley, '25). It is apparent from table 2 that bones of the brain case and auditory capsules begin to ossify before metamorphosis, whereas bones of the visceral skeleton and nasal capsules ossify after the onset of metamorphosis at stage XVIII. Although the table was derived from observations on laboratory-reared specimens, we found that ossification of skull bones in five metamorphosing animals collected from nature at stages XVIII-XXII conformed to the sequence tabulated for laboratory animals.

\section{Premetamorphic cranial bones}

Parasphenoid (IV-IX). This crossshaped bone forms the floor of the cranium and is the earliest skull bone to ossify. It tends to ossify in advance of exoccipitals and vertebrae, although the ranges for beginning ossification in these axial skeletal elements overlap. The main shaft of the parashpenoid extends longitudinally beneath the chondrocranium, and its lateral wings extend beneath the auditory capsules. Deposition of mineral begins between the auditory capsules but soon thereafter is evident along the lateral margins of the main shaft. The two lateral spikes elongate anteriorly, and bone gradually fills in the unossified gap between them (figs. 1-6). Mineralization is slower in the wings of the parasphenoid than in the shaft. Treatment with thyroxine for four days (Kemp and Hoyt, '65a) or even 
TABLE 2

Order of ossification of skull bones in Rana pipiens tadpoles as indicated by alizarin staining

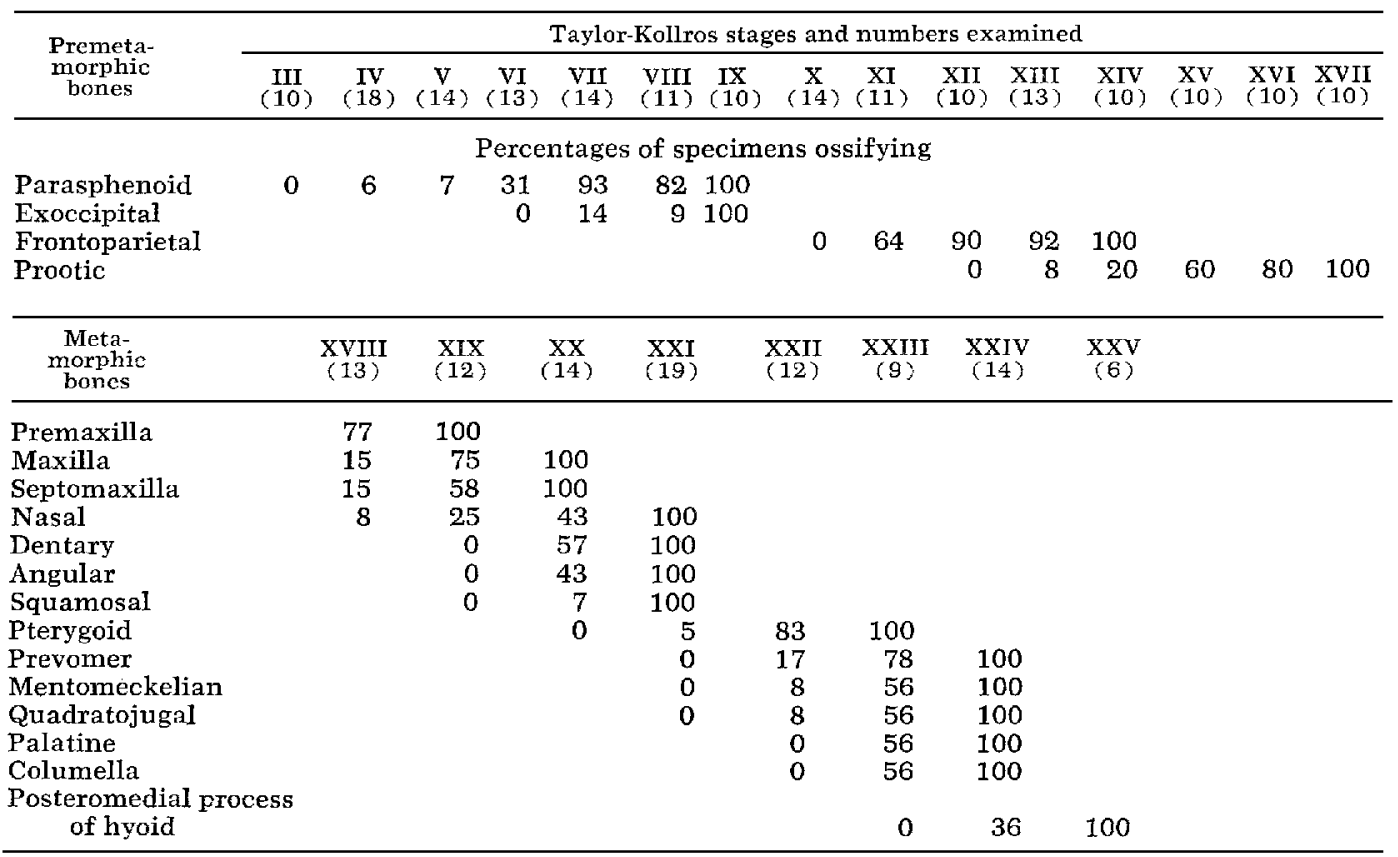

up to ten days, beginning at stage IX, did not enhance mineralization of the parasphenoid. We have unpublished electron microscopic evidence that exogenous thyroxine administered at stage IX may cause diminished ossification of the parasphenoid.

Exoccipital (VII-IX). Two distinct mineralizing centers, which later fuse, are the primordia for each of the paired exoccipital bones. The first center is a wedge of bone lying between the auditory capsule and the parachordal cartilage. This center resembles a neural arch (fig. 2). It later expands to form the posterior wall of the skull as well as portions of its floor and roof around the foramen magnum. The second center of the exoccipital appears shortly after the first (fig. 4) and is comprised of sheets of bone arising on the postero-medial surface of the auditory capsule. These sheets spread to cover the posterior face of the auditory capsule.

Frontoparietal (XI-XIV). Frontals and parietals arise separately (fig. 3 ). Mineralization of the frontals begins with the ap- pearance of elongated, slender rudiments laterally in the region of the future roof of the skull. Parietals appear posterior to the frontals as small round or crescentshaped patches of bone above the anterolateral curves of the optic lobes of the brain (fig. 3). Frontals widen by addition of bone medially, particularly toward their caudal ends (figs. 4, 5). The crescentshaped parietals widen together with the frontals and fuse with the latter by stage XVII (fig. 6). The medial gap between the paired frontoparietals persists until after metamorphosis.

Prootic (XIII-XVII). Three separate sheets of bone arise and then fuse to form each of the paired prootics. The first sheet appears on the inner surface of the anteromedial margin of the auditory capsule (fig. 5). This sheet is then joined by a second which covers the outer surface of the anterior face of the auditory capsule. The third rudiment of the prootic is medial to the other two and extends around the side of the optic lobe of the brain. 


\section{Metamorphic cranial and visceral skeletal bones}

Premaxilla (XVIII-XIX). The appearance of the paired premaxillae at the beginning of metamorphosis heralds the major structural changes which accompany differentiation of the jaws and nasal capsules. Initially the premaxilla is shieldshaped and lies on the suprarostral cartilage (figs, 7-10). Primary growth is dorsoventral with a medial spine forming dorsally. Continued growth results in widening of the ventral portion of the premaxilla. Its medial and lateral margins then grow sharply inward to form ventro-medial and ventro-lateral projections (figs. 15, 17). A horizontal shelf of bone, the palatine process (DeBeer, '37), develops between these projections (figs. 15, 17) and later serves as a base for attachment of premaxillary teeth.

Maxilla (XVIII-XX). The bilateral ascending (facial) portion of the maxilla adjacent to the premaxilla is the first to ossify (figs. 8, 10). This portion is carried posteriorly as the palatoquadrate cartilage regresses; but the ascending portion continues to grow by addition of bone anteriorly (figs. 12, 14). Along the medial surface a horizontal palatine process develops in line with the palatine process of the premaxilla and later supports the anterior maxillary teeth. After the ascending portion reaches a position beneath the posterior tip of the nasal bone (figs. 1518), mineralization of the alveolar portion (DeBeer, '37) proceeds chiefly in a caudal direction. Posterior growth continues until it articulates with the quadratojugal (figs. 20, 22).

Septomaxilla (XVIII-XX). This bone develops bilaterally around the lateral margin of the external naris (figs. 8, 10). It develops as a U-shaped support around the lateral aspect of the anterior end of the nasal capsule (figs. 11-12).

Nasal (XVIII-XXI). The time of appearance of the nasals is more irregular than for the premaxillae, maxillae and septomaxillae. The nasal first appears as a slender plate of bone anterior to the frontoparietal and projecting postero-laterally at an angle of about $45^{\circ}$ (figs. 8 , 10). The dorsal portion of the nasal widens to form a thin roof over the nasal capsule, while the ventral portion elongates (figs. 19-22) to form a thickened "rib" over the lateral surface of the nasal capsule.

Dentary (XX-XXI). The paired rudiments of the dentary, angular and squamosal begin to ossify at about the same time. of 14 specimens examined at stage $\mathrm{XX}$, three had dentaries but no angulars; one had angulars without accompanying dentaries, and five had both pairs of bones. The dentary first forms as a sliver of bone on the antero-lateral surface of Meckel's cartilage (figs. 11, 13). It then grows posteriorly over the dorso-lateral surface of this cartilage (figs. 12-22). A ventral extension of the anterior tip of the dentary fuses with the mentomeckelian bone toward the end of metamorphosis.

Angular (XX-XXI). The angular appears bilaterally as a flat, porous bone on the ventro-medial aspect of Meckel's cartilage and eventually comprises a major portion of the lower jaw (figs. 12-22). Angular and dentary have surrounded most of Meckel's cartilage by the end of metamorphosis but still have not joined by that time.

Squamosal (XX-XXI). The squamosal usually appears at stage XXI on the anterolateral border of the orbit. Initially it is a slender, curved bone with a dorsal portion oriented vertically and a ventral portion sloping anteriorly (figs. 12, 14). The squamosal develops bilaterally on the outer surface of the quadrate region (suspensorium) of the palatoquadrate cartilage and is carried posteriorly as metamorphosis proceeds (figs. 15-18), During its caudad migration the squamosal becomes straighter and thicker; furthermore its slope relative to the dorso-ventral axis changes. When it reaches a position lateral to the prootic, it has become almost vertical (figs. 19, 21). The dorsal end of the squamosal now remains lateral to the prootic; but the ventral end shifts farther caudad as the jaw elongates (figs. 20, 22), a process which continues after metamorphosis. Growth of the dorsal end of the squamosal remains limited until about stage XXIV, when a posterior process begins to grow back over the lateral surface 
of the auditory capsule (figs. 19-22). After metamorphosis an anterior or zygomatic process grows forward from the dorsal end of the squamosal.

Pterygoid (XXI-XXIII). This bone arises bilaterally on the medioventral surface of the pterygoid portion of the palatoquadrate cartilage (DeBeer, '37) roughly underlying the squamosal. It is a Y-shaped bone with one arm extending forward to the maxilla, and forking posteriorly into an arm abutting against the prootic and an arm extending to the articular surface of the quadrate cartilage. The forward arm extending toward the maxilla appears first at about stage XXII as a slender bone lateral to the orbit and in the same plane as the parasphenoid (figs. 15, 17). The second arm appears postero-laterally from the first as an irregular, spreading patch of bone medial to the squamosal (figs. 16, 18). At about stage XXIV the second arm fuses dorsally with the antero-medial arm at an angle of about $90^{\circ}$ (figs. 19, 21). As the angle of the jaws migrates posteriorly, the antero-medial arm of the pterygoid thickness and lengthens and curves laterad toward the maxilla at its anterior end. At the same time the second arm shifts backward along with the ventral portion of the squamosal (figs. 20, 22) and forms an obtuse angle with the antero-medial arm. A third arm, which extends toward the prootic, has begun to develop by stage XXV (figs, 20,22), and also by this time the antero-medial arm is being reinforced by a ventro-lateral spur (figs. $20,22)$.

Prevomer (XXII-XXIV). The prevomers appear as a pair of small, irregular patches of bone anterior to the growing tips of the parasphenoid (figs. 16, 18). As they grow out antero-laterally (figs. 20, $22)$, they produce three lateral prongs. The more posterior (third) and middle (second) of these prongs form around the medial border of the internal naris. Prevomerine teeth begin to calcify beneath the medial shaft of the prevomer even before mineralization of the forked lateral end is under way.

Mentomeckelian (XXII-XXIV). This cartilage bone appears bilaterally at about the same time as the prevomer, quadrato- jugal, palatine and columella. It begins as a tiny sliver of bone medial to the anterior tip of the dentary (figs. 16, 18). Shortly after its appearance it becomes joined to the dentary by a fragile bridge of porous bone. This bridge was present in two of five specimens with dentaries at stage XXIII and in all of six specimens examined at stage XXV.

Quadratojugal (XXII-XXIV). This bone develops bilaterally between the quadrate cartilage, at the base of the squamosal, and the posterior end of the maxilla. The articulating head of the quadratojugal is considered to be cartilage bone, whereas its shaft is dermal bone (Gaupp, 1896, '06). The primordium is a small patch of bone ventral and slightly anterior to the squamosal (figs. 16, 18). This ossified area thickens, and a slender extension grows antero-dorsad from it toward the maxilla (figs. 19-22). The quadratojugal shifts caudally along with the squamosal and pterygoid as the posterior angle of the jaws moves backward.

Palatine (XXIII-XXIV). The paired palatines develop beneath the palatine portions of the palatoquadrate cartilages in the same plane as the parasphenoid. The palatine is a narrow bone which thickens slightly by the end of metamorphosis (figs. 20,22 ), but it has not yet grown out to contact the maxilla by that time.

Columella (XXIII-XXIV). The columella auris, also known as the mediostapedial (DeBeer, '37), develops by ossification of the middle portion of a cartilaginous pre. cursor between the fenestra ovalis of the auditory capsule and the tympanum. The columella is a derivative of the hyoid arch. It develops with an expanded base from which extends a short lateral stalk (figs. $16,18 ; 19-22)$.

Posteromedial process of hyoid (XXIVXXV). The paired posteromedial or thyroid processes (DeBeer, '37) are ossified posterior extensions of the hypobranchial plate, loosely termed the body of the "hyoid" (Villee, Walker and Smith, '68). They are not illustrated because they were removed during preparation of the specimens for photography.

Sphenethmoid. This bone develops bilaterally between the anterior ends of the 
frontoparietals and the parasphenoid but does not ossify until after metamorphosis.

\section{DISCUSSION}

On the basis of Erdmann's ('33) study, DeBeer ('37) lists the following order of ossification of bones of the osteocranium of Rana fusca (synoym temporaria) : parasphenoid, frontal, exoccipital, parietal and premaxilla before metamorphosis; septomaxilla, maxilla, prootic, dentary, angular squamosal, quadratojugal, pterygoid, mentomeckelian during metamorphosis; and nasal, prevomer, palatine, posteromedial process of hyoid, and sphenethmoid after metamorphosis.

Our study indicates that the order of ossification of these bones in Rana pipiens is: parasphenoid, exoccipital, frontal and parietal (frontoparietal), and prootic before metamorphosis; premaxilla, maxilla, septomaxilla, nasal, dentary, angular, squamosal, pterygoid, prevomer, mentomeckelian, quadratojugal, palatine, columella, posteromedial process of hyoid during metamorphosis; sphenethmoid after metamorphosis. The prootic early and later the nasal, prevomer, palatine and posteromedial process of the hyoid thus ossify sooner in Rana pipiens than in Rana temporaria. DeBeer's ('37) discussion of the order of appearance of cartilage bones (exoccipital, prootic, mediostapedial, mentomeckelian, posteromedial process of hyoid, sphenethmoid) indicates that the columella (mediostapedial) ossifies at about the same time in the two species.

Generalizing from the chronology in $R$. pipiens and $R$. temporaria, we may infer that in Ranidae bones surrounding the chondrocranium and auditory sense capsules begin to ossify before metamorphosis, while bones of the jaws and nasal capsules ossify during or after metamorphosis. Early ossification of the exoccipitals in Rana pipiens may be an indicator of their serial homology with vertebrae, which also begin to ossify at the same time. Hylid anurans (Stokely and List, '54; Trueb, '66) have a markedly different order of ossification than do ranids. According to Trueb ('66), in Hyla septentrionalis the dentigerous dermal bones (premaxilla, maxilla, prevomer) develop early, followed by dermal bones of the lower jaw and cranium, and finally by endochondral bones (exoccipital, prootic, mentomeckelian, sphenethmoid and columella).

Ossification of the skull in urodeles begins somewhat earlier in larval development than in anurans. Primordia of dentary, angular and pterygopalatine bones begin to mineralize even before hatching in embryos of Siredon, Salamandra and Triton (Gaupp, '06). As in the hylids, dentigerous bones of urodeles develop relatively early (Gaupp, '06; Erdmann, '33). These include the vomer, palatine, opercular (splenial) and parts of the premaxilla, maxilla and dentary). A recent study by Corsin ('66) shows that this generalization holds for the dentigerous bones of Pleurodeles waltiii except for the maxilla, which is the next-to-the-last bone to ossify in this species. DeBeer ('37) has stated "that there is no correspondence whatever in the relative times at which homologous bones arise" in the skulls of Triton alpestris and Rana fusca.

What accounts for variations in the chronology of skeletogenesis in animals of related taxa? Ultimately the explanation depends on sequential activation of genes in osteoblasts of particular mineralizing sites. The basic question is: What turns on the osteogenic genes? Our studies with thyroxine-treated tadpoles (Kemp and Hoyt, '65c) indicate that thyroid hormones may play an important role in stimulating osteogenesis. Evidence from in vitro studies on limb bone rudiments (Fell and Mellanby, '55, '56; Lengemann, '62; Lawson, '63; Gaillard, '63) suggests that both thyroid and parathyroid hormones may induce maturative changes in explanted rudiments. Species variations in levels of circulating thyroid hormones at successive stages of larval development may be one factor in regulating ossification. Differences in thresholds of response (Kollros, '61; Etkin, '64) of osteogenic sites undoubtedly help to regulate sequence of ossification. Availability of metastable mineralizing ions (Glimcher, '60), chemical interactions between collagen and mucopolysaccharides of bone matrix (Weidmann, '63), vitamin D, hormones of the adrenal glands and gonads 
(Gorbman and Bern, '62), and mechanical stress (Weisel, '67) are additional factors which affect bone development.

It is significant that the order of ossification of limb bones is the same in thyroxine-treated tadpoles and in untreated controls (Kemp and Hoyt, '65c). Skeletogenesis appears to be epigenetic, one phase leading to the next in an ordered sequence. We found though that treatment with thyroxine could change the normal order of ossification of skull bones. Precocious ossification of the premaxilla occurred in eight tadpoles treated with thyroxine for 7-11 days, beginning at stages IV to IX (Kemp and Hoyt, '65b). The prootic was by-passed in all of these animals. Five of the eight had ossifying maxillae and septomaxillae in addition to the premaxillae. This result seems to show that thyroxine may influence which mineralizing sites become most competitive for available mineralizing ions. Normally ossification of the parasphenoid and other cranial bones establishes a firm longitudinal support for the skull before metamorphosis. Two of the eight tadpoles with precocious premaxillae were treated for 11 days beginning at stages IV or V. Skulls in these two animals appeared excessively short, because neither the parasphenoid nor the prootics became ossified.

How may thyroid hormones function in stimulating osteogenesis? In our experiments with thyroxine-treated tadpoles (Kemp and Hoyt, '65c) we found that proliferation of endoplasmic reticulum begins in osteoblasts of the femur about two days after beginning treatment at stage IX, when the limb skeleton is still unossified (Dunlap, '66). Mineralization of the osteoid matrix in our treated specimens did not begin until about day 6 of treatment. We have speculated that mineralization of osteoid matrix may be dependent on depolymerization of ground substance and/or collagen in the matrix. Glimcher ('60) has discussed the possible roles of ground substance in shielding reactive mineralizing sites on collagen fibrils. Weidmann ('63) has discussed the alternative hypothesis that chondroitin sulfate by itself or in combination with collagen is responsible for initiating nucleation of hydroxyapatite crystals.
Collagen is the principal protein secreted by osteoblasts into osteoid matrix (Tonna, '65); but non-collagenous protein forms mucopolysaccharide-protein complexes in bone matrix (Glimcher, '60). Thyroxine is known to stimulate protein synthesis in target cells and may have a primary stimulating effect on mitochondria (Hoch, '68). Whether thyroxine stimulates osteoblasts to secrete depolymerases as a prelude to mineralization has yet to be determined. Hyaluronidase and collagenase have been detected in tadpole tailfins (Eisen and Gross, '66), and the latter enzyme has been found in mammalian bones (Woods and Nichols, '65). Dziewiatkowski ('66) has shown that calf cartilage contains a depolymerase capable of degrading proteinpolysaccharide extracted from calf cartilage.

This study has shown that the TaylorKollros stages of growing and metamorphic tadpoles provide a reliable index to the state of ossification of the skeleton of Rana pipiens. Rate of growth or metamorphosis of tadpoles undoubtedly affects the exact stage of appearance of a particular bone. We have noticed that the time of appearance may vary slightly in slow-growing and fast-growing animals. One would expect nutritional variations to account for specific delays or acceleration in skeletogenesis. It is really not surprising that there is good correlation between the Taylor-Kollros stages and the state of development of the skeleton. Stages I-XX of the Taylor-Kollros series are based primarily on external features of the limbs, and stages XXI-XXIII on transformation of the jaws. Both sets of criteria depend heavily on accompanying skeletal changes.

\section{LITERATURE CITED}

Corsin, J. 1966 The development of the osteocranium of Pleurodeles waltlii Michahelles. J. Morph., 119: 209-216.

DeBeer, G. R. 1937 Development of the Vertebrate Skull. Oxford University Press.

Dunlap, D. G. 1966 The development of the musculature of the hindlimb of the frog, Rana pipiens. J. Morph., 119; 241-258.

Dziewiatkowski, D. D. 1966 Role of proteinpolysaccharides in calcification. Birth Defects Original Article Series, The Natl. Foundation, 2: $31-34$.

Eisen, A. Z., and J. Gross 1966 The role of epithelium and mesenchyme in the production 
of a collagenolytic enzyme and a hyaluronidase in the anuran tadople. Develop. Biol,, 12: 408418 .

Erdmann, K. 1933 Zur Entwicklung des knöchernen Skelets von Triton und Rana unter besonderer Berücksichtigung der Zeitfolge der Ossifikationen. Zeitschr. f. Anat. u. Entw. Gesch., 101: 566-651.

Etkin, W. 1964 Metamorphosis. In: Physiology of the Amphibia. J. A. Moore, ed., pp. 427468. Academic Press, New York.

Fell, H. B., and E. Mellanby 1955 The biological action of thyroxine on embryonic bones grown in tissue culture. J. Physiol,, 127: 427447.

- 1956 The effect of l-triiodothyronine on the growth and development of embryonic chick limb-bones in tissue culture. J. Physiol., 133: 89-100.

Fox, E., and J. T. Irving 1950 The effect of thyroid hormone on the ossification of the femur in Xenopus laevis tadpoles. S. African J. Med. Sci., 15: 11-14.

Gaillard, P. J. 1963 Observations on the effect of thyroid and parathyroid secretions on ex$\mathrm{F}^{\circ}$ anted mouse radius rudiments. Develop. Biol., 7; 103-116.

Gaupp, E. 1896 A. Ecker's und R. Wiedersheim's Anatomie des Frosches. I. Lebre vom Skelet und vom Muskelsystem. Friedrich Vieweg und Sohn, Braunschweig.

1906 Die Entwickelung des Kopfskelet. tes. In: O. Hertwig's Handbuch der vergleichenden und experimentellen Entwickelumgslehre der Wirbeltiere, 3 (2): 573-874. Gustav Fischer, Jena.

Glimcher, M. J. 1960 Specificity of the molecular structure of organic matrices in mineralization. In: Calcification in Biological Systems (R. F. Sognnaes, ed.), pp. 421-487. A.A.A.S. Publ. No. 64, Washington, D. C.

Goodrich, E. S. 1958 Studies on the Structure and Development of Vertebrates. Vol. 1. Dover Publ., Inc., New York.

Gorbman, A., and H. Bern 1962 A 'Textbook of Comparative Endocrinology. John Wiley and Sons, New York.

Hoch, F. L. 1968 Biochemistry of hyperthyroidism and hypothyroidism Postgrad. Med. J., 44: 347-362.

Holmes, S. J. 1912 The Biology of the Frog, 2nd ed. The Macmillan Co., New York.

Kaltenbach, J. C. 1953 Local action of thyroxine on amphibian metamorphosis. I. Local metamorphosis in Rana pipiens larvae effected by thyroxin-cholesterol implants. J. Exp. Zool,, 122: 41-51.

Kemp, N. E., and J. A. Hoyt 1965a InHuence of thyroxine on ossification of the parasphenoid bone in the skull of Rana pipiens. Am. Zool., 5: 710 .

1965b Influence of thyroxine on order of ossification of bones of the skull of Rana pipiens. Am. Zool., 5: 719 .

$1965 \mathrm{c}$ Influence of thyroxine on ossification of the femur in Rana pipiens. J. Cell Biol., 27: 51A.

Kingsley, J. S. 1925 The Vertebrate Skeleton from the Developmental Standpoint. P. Blakiston's Son and Co., Philadelphia.

Kollros, J. J. 1961 Mechanisms of amphibian metamorphosis: hormones. Am. Zool., 1: 107114.

Kuhn, O., and H. O. Hammer 1956 über die Einwirkung des Schilddrüsenhormons auf die Ossifikation. Experientia, 12: 231-233.

Lawson, K. 1963 The differential growth-response of embryonic chick limb-bone rudiments to triiodothyronine in vitro. III. Hormone concentration. J. Embryol. Exptl. Morphol., 11: 383-398.

Lengemann, F. W. 1962 Effects of thyroxine upon strontium and calcium metabolism of embryonic bone grown in vitra. Endocrinol., 70: $774-780$.

Mayorga, H. 1964 Metodo rapido para transparentar anfibios y colorear esqueletos. Carib. J. Sci., 4: 323-325.

McEwen, R. S. 1957 Vertebrate Embryology, 4th ed. Henry Holt and Co., New York.

Moss, M. L. 1960 Experimental induction of osteogenesis. In: Calcification in Biological Systems. R. F. Sognnaes, ed., pp. 323-348. A.A.A.S. Publ. No. 64, Washington, D.C.

Parker, W. K. 1871 On the structure and development of the skull of the common frog (Rana temporaria, L.). Phil, Trans. Roy. Soc. London, 161: 137-211.

-_ 1876 On the structure and development of the skull in the Batrachia. Part II. Phil. Trans. Roy. Soc. London, 166: 601-669.

1881 On the structure and development of the skull in the Batrachia. Part III, Phil. Trans Roy. Soc. London, 172(1): 1-266.

Stokely, P. S., and J. S. List 1954 Progress of ossification in the skull of the cricket frog Pseudacris nigrita triseriata. Copeia, 1954 (3): 211217.

1955 Observations on the development of the anuran urostyle. Trans. Am. Microscop. Soc., 74: 112-115.

Taylor, A. C., and J. J. Kollros 1946 Stages in the normal development of Rana pipiens larvae. Anat. Rec., 94: 7-24.

Tonna, E. A. 1965 Protein synthesis and cells of the skeletal system. In: The use of Autoradiography in Investigating Protein Synthesis. C. P. LeBlond and K. B. Warren, eds., pp. 215245. Academic Press, New York.

Trueb, L. 1966 Morphology and development of the skull in the frog Hyla septentrionalis. Copeia, 1966 (3): 562-573.

Villee, C. A., W. F. Walker, Jr. and F. E. Smith 1968 General Zoology, 3rd ed. W. B. Saunders Co., Philadelphia.

Weidmann, S. M. 1963 Calcification of skeletal tissues. Int. Rev. Conn. Tissue Res., 1: 339377.

Weisel, G, F. 1967 Early ossification in the skeleton of the sucker (Catostomus macrocheilus) and the guppy (Poecilia reticulata). J. Morph., 121: 1-18.

Woods, J. F., and G. Nichols, Jr. 1965 Collagenolytic activity in rat bone cells. Characteristics and intracellular location. J. Cell Biol., 26: $747-758$. 


\section{Abbreviations}

$\begin{array}{ll}\text { An, Angular } & \text { Po, Prootic } \\ \text { Co, Columella } & \text { Pm, Premaxilla } \\ \text { De, Dentary } & \text { Ps, Parasphenoid } \\ \text { Ex, Exoccipital } & \text { Pt, Pterygoid } \\ \text { Fp, Frontoparietal } & \text { Pv, Prevomer } \\ \text { Ma, Maxilla } & \text { Qu, Quadratojugal } \\ \text { Mm, Mentomeckelian } & \text { Sm, Septomaxilla } \\ \text { Na, Nasal } & \text { Sq, Squamosal } \\ \text { Pa, Palatine } & \end{array}$

\section{PLATE 1}

EXPLANATION OF FIGURES

Drawings of ventral views of alizarin-stained skulls showing bones ossifying before metamorphosis.

1 Taylor-Kollros stage VII. Bone present: Ps.

2 Stage IX. Bones present: Ex, Ps.

3 Stage XI. Bones present: Ex, Fp, Ps.

4 Stage XIII. Bones Present: Ex, Fp, Ps.

5 Stage XV. Bones present: Fx, Fp, Po, Ps.

6 Stage XVII. Bones present: Ex, Fp, Po, Ps. 
VII
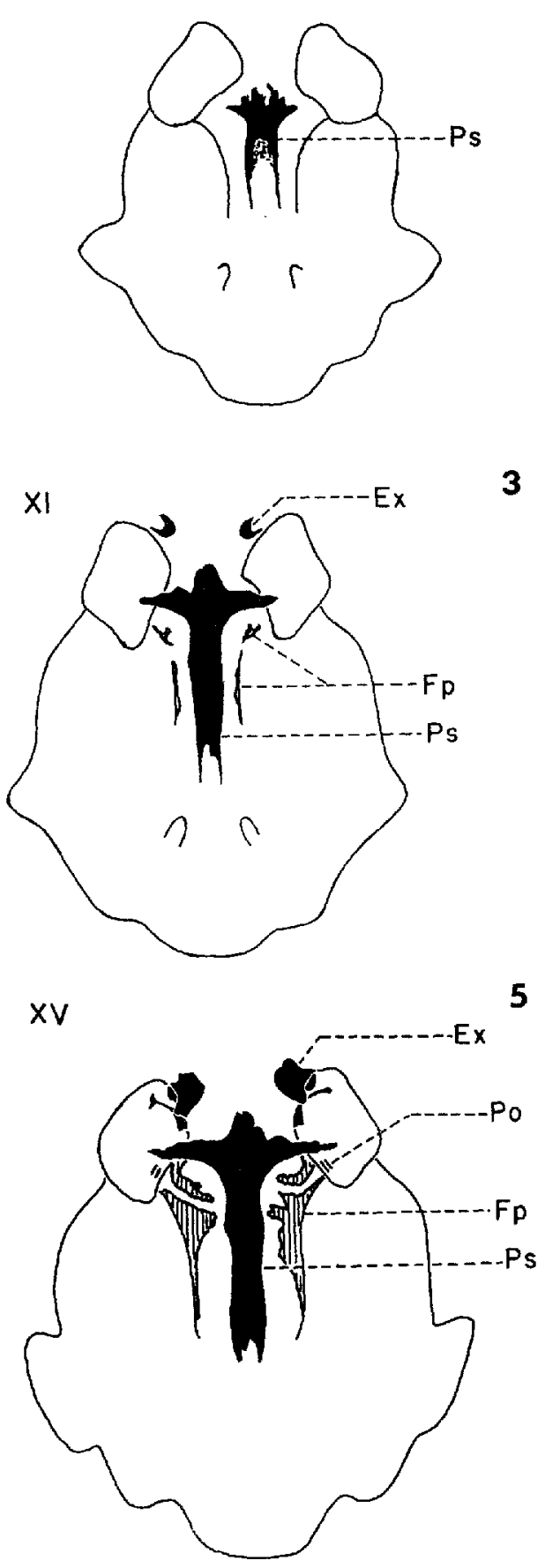

3
$1 \quad$ IX

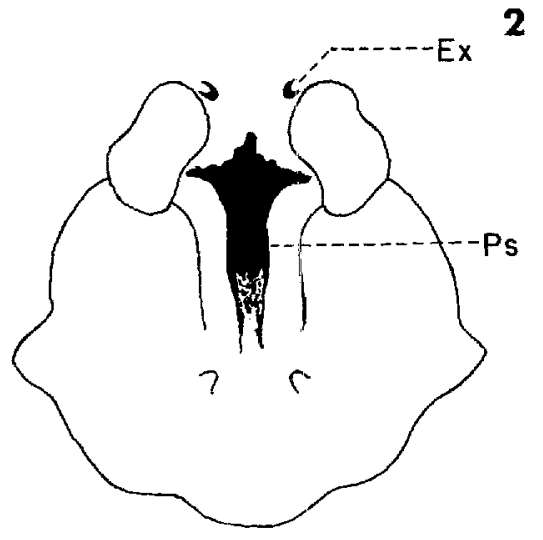

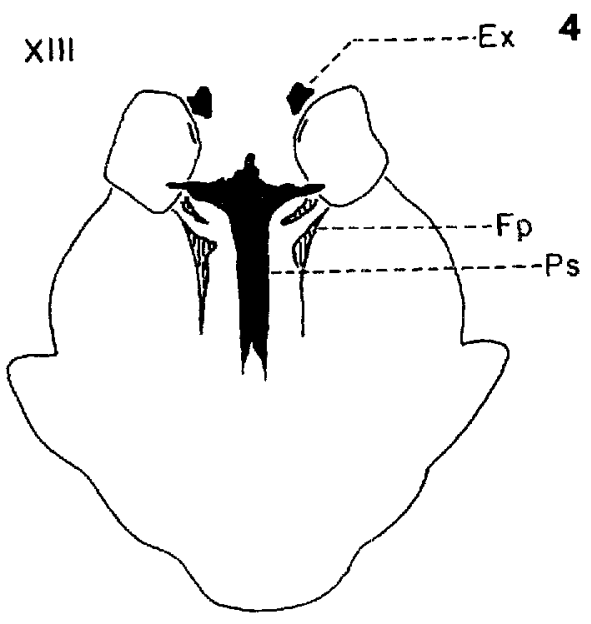

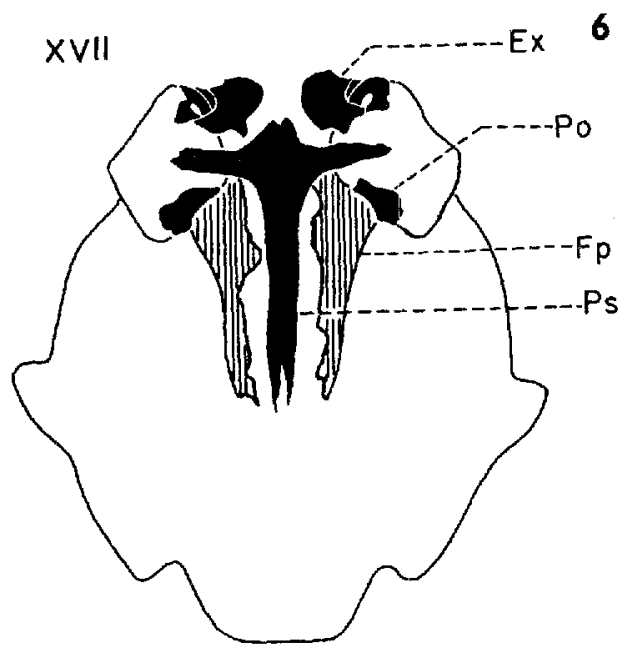


PLATE 2

EXPLANATION OF FIGURES

Photographs of dorsal (a), ventral (b) and lateral (c) views of alizarin-stained skulls showing bones ossifying at metamorphic stages XVIII and XIX. Explanatory drawings are in plate 3.

7 Stage XVIII. $\times 5$

8 Stage XIX. $\times 5$ 


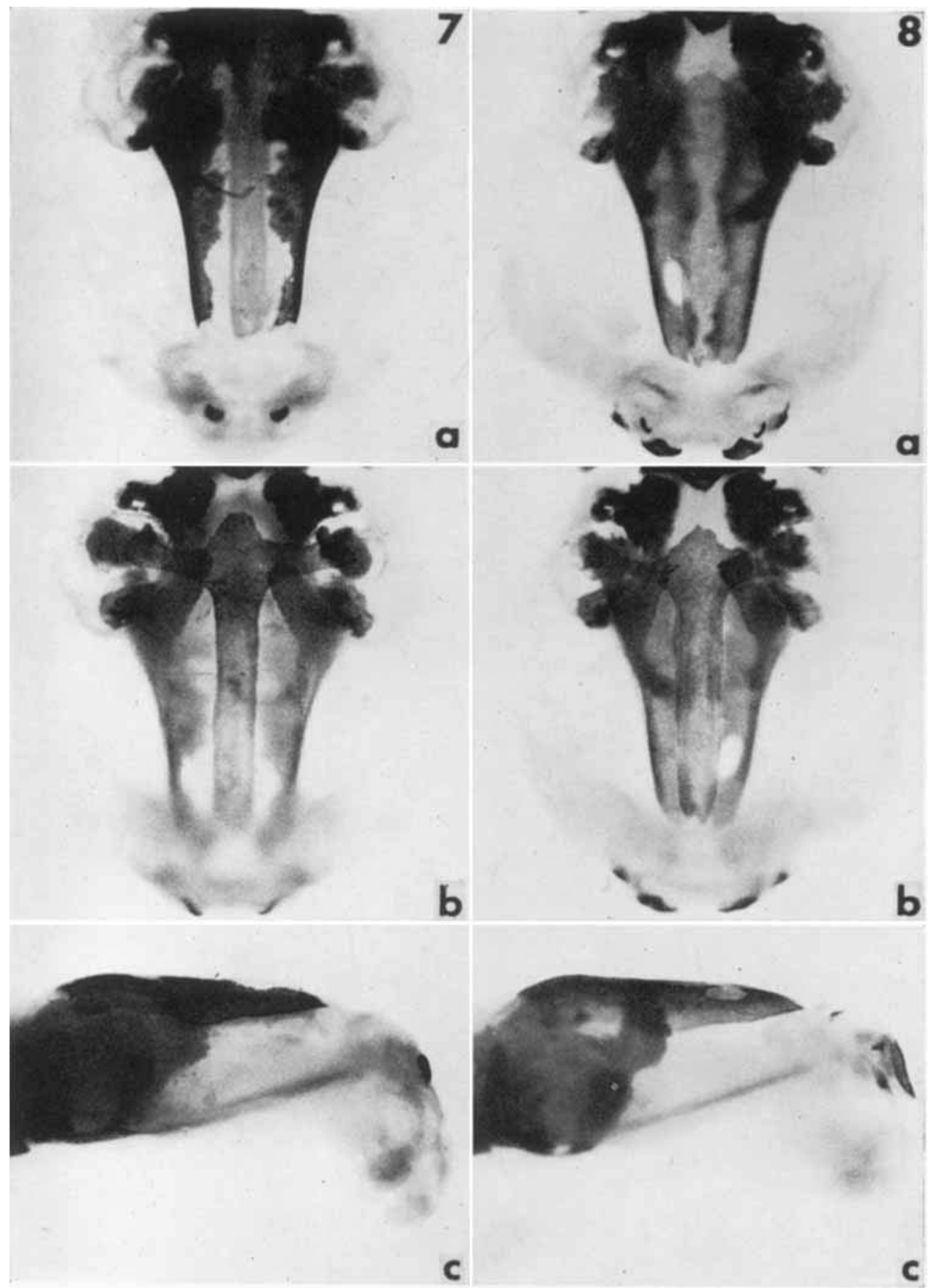


PLATE 3

EXPLANATION OF FIGURES

Drawings of dorsal (a), ventral (b) and lateral (c) views of alizarinstained skulls showing bones ossifying at metamorphic stages XVIII and XIX. Drawings based on photographs in plate 2.

9 Stage XVIII. Bones present: Ex, Fp, Pm, Po, Ps.

10 Stage XIX. Bones present: Ex, Fp, Ma, Na, Pm, Po, Ps, Sm. 

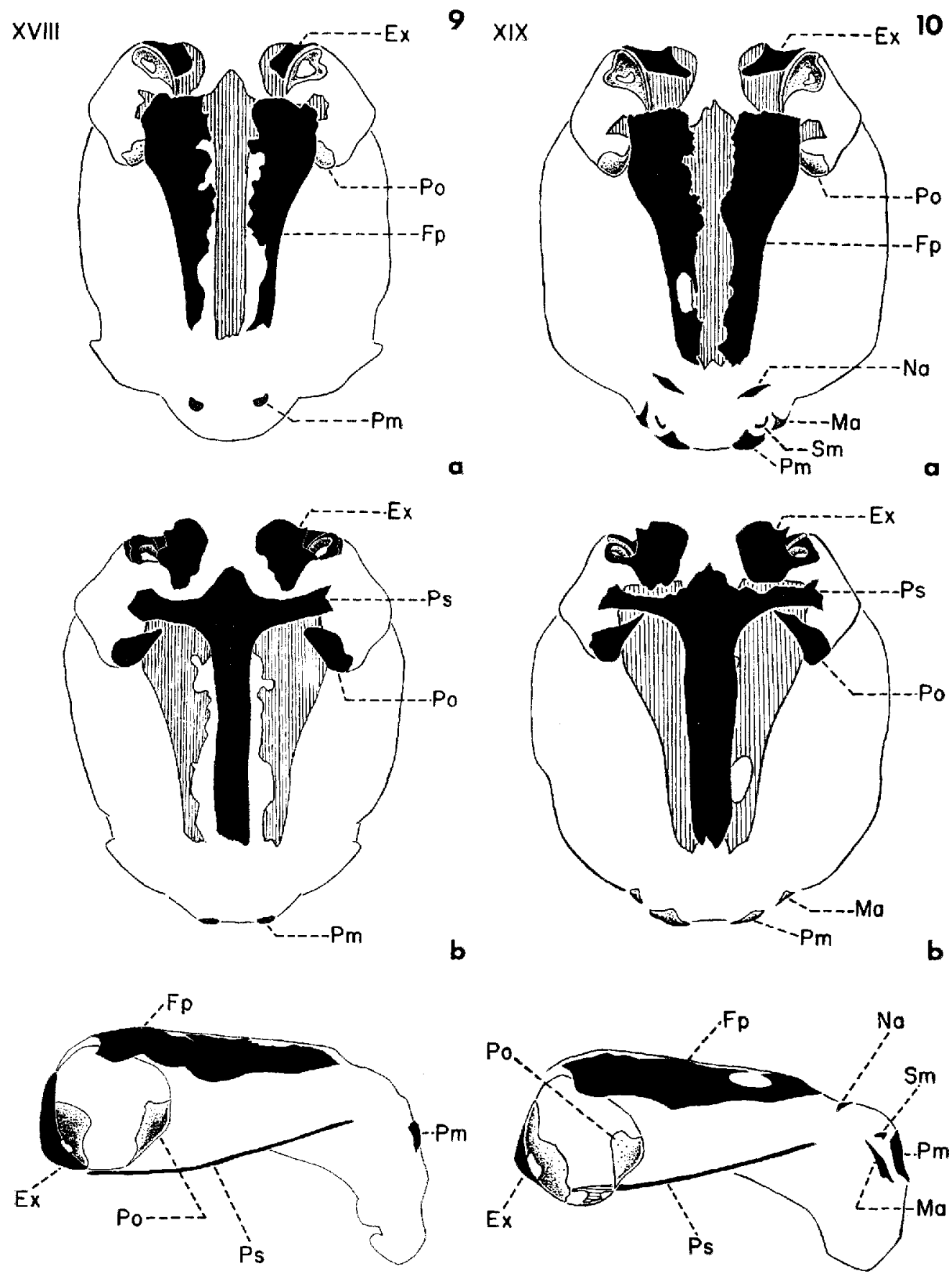

C 


\section{PLATE 4}

EXPLANATION OF FIGURES

Photographs of dorsal (a), ventral (b) and lateral (c) view of alizarinstained skulls showing bones ossifying at metamorphic stages $\mathrm{XX}$ and XXI. Explanatory drawings are in plate 5 .

11 Stage $\mathrm{XX} . \times 5$.

12 Stage XXI. $\times 5$. 


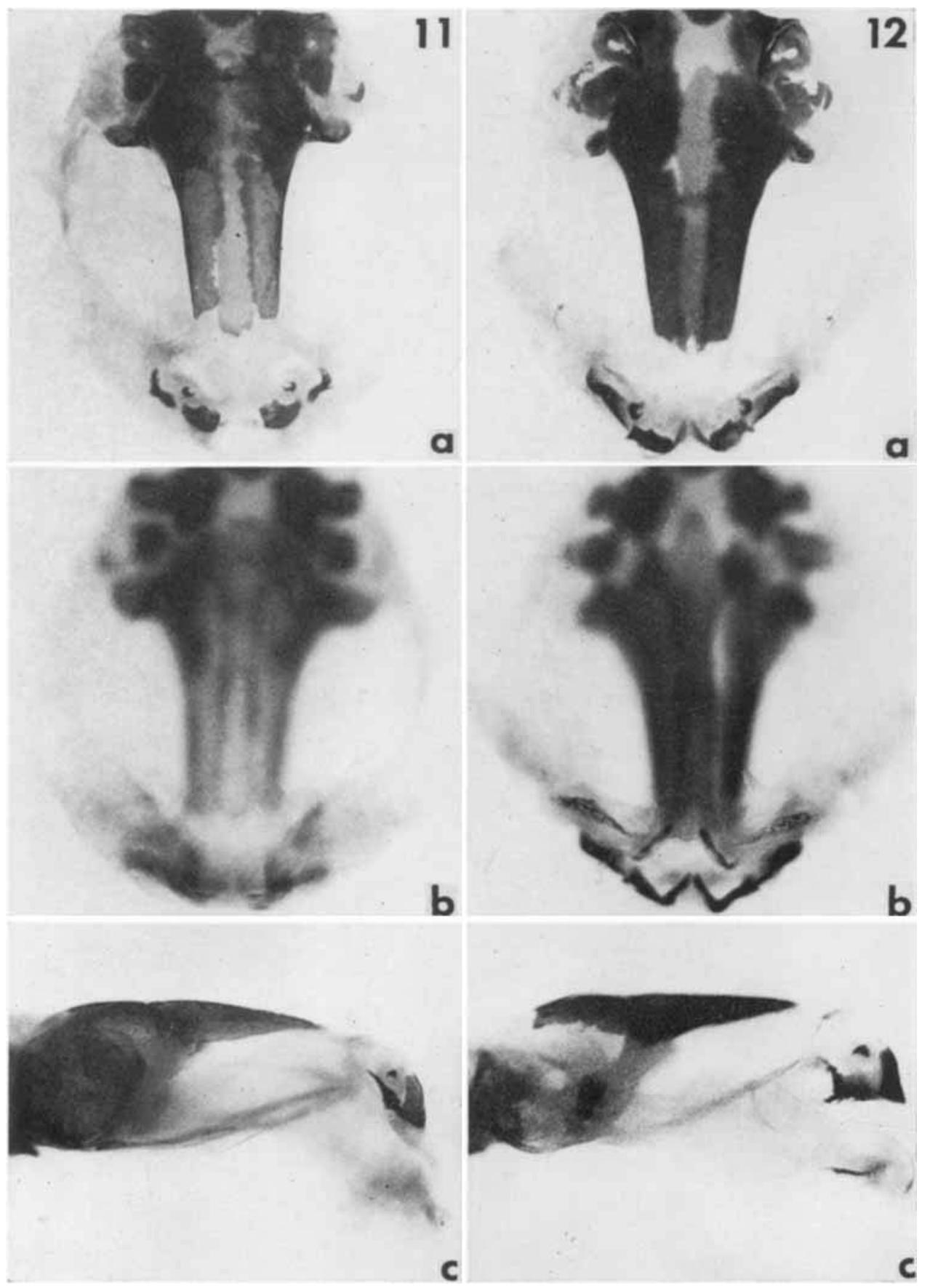


PLATE 5

EXPLANATION OF FIGURES

Drawings of dorsal (a), ventral (b) and lateral (c) views of alizarinstained skulls showing bones ossifying at metamorphic stages XX and XXI. Drawings based on photographs in plate 4 .

13 Stage XX. Bones present: De, Ex, Fp, Ma, Pm, Po, Ps, Sm.

14 Stage XXI. Bones present: An, De, Ex, Fp, Ma, Na, Pm, Po, Ps, Sm, Sq. 

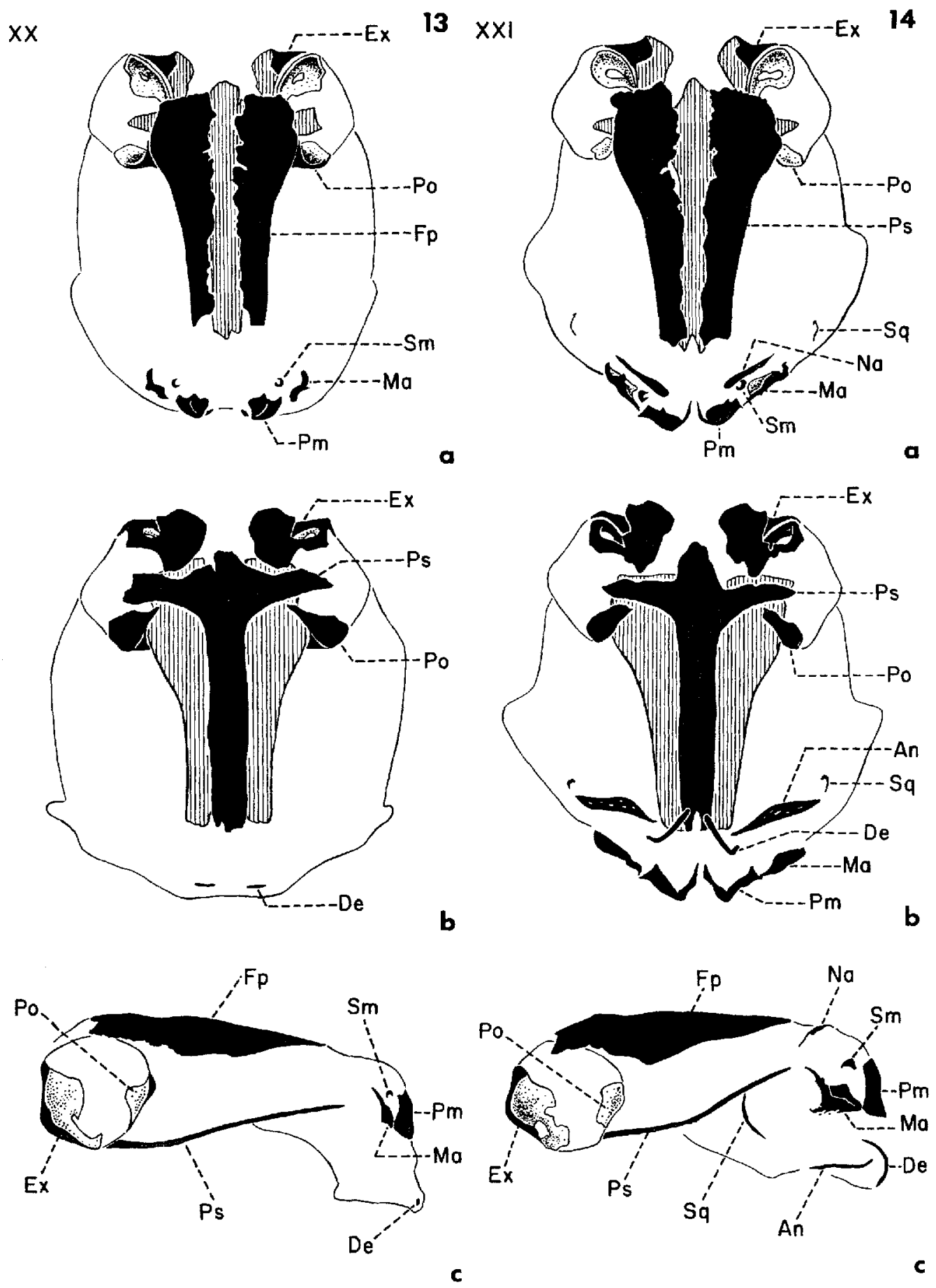
PLATE 6

EXPLANATION OF FIGURES

Photographs of dorsal (a), ventral (b) and lateral (c) views of alizarinstained skulls showing bones ossifying at metamorphic stages XXII and XXIII. Explanatory drawings are in plate 7 .

15 Stage XXII. $\times 5$.

16 Stage XXIII. $\times 5$. 


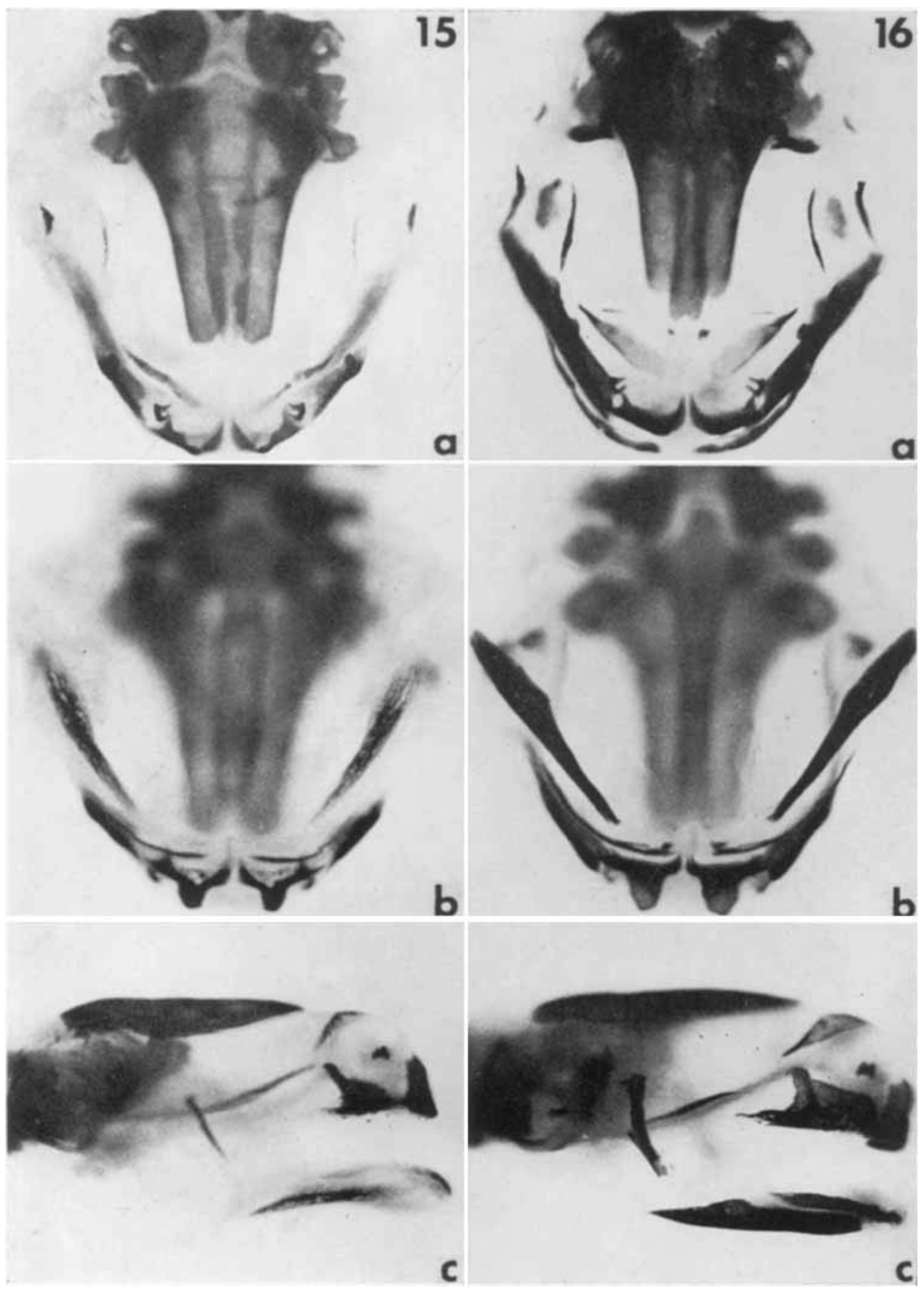


PLATE 7

EXPLANATION OF FIGURES

Drawings of dorsal (a), ventral (b) and lateral (c) views of alizarinstained skulls showing bones ossifying at metamorphic stages XXII and XXIII. Drawings based on photographs in plate 6 .

17 Stage XXII, Bones present: An, De, Ex, Fp, Ma, Na, Pm, Po, Ps, Pt, Sm, Sq.

18 Stage XXIII. Bones present: An, Co, De, Ex, Fp, Ma, Mm, Na, Pa, Pm, Po, Ps, Pt, Qu, Sm, Sq. 

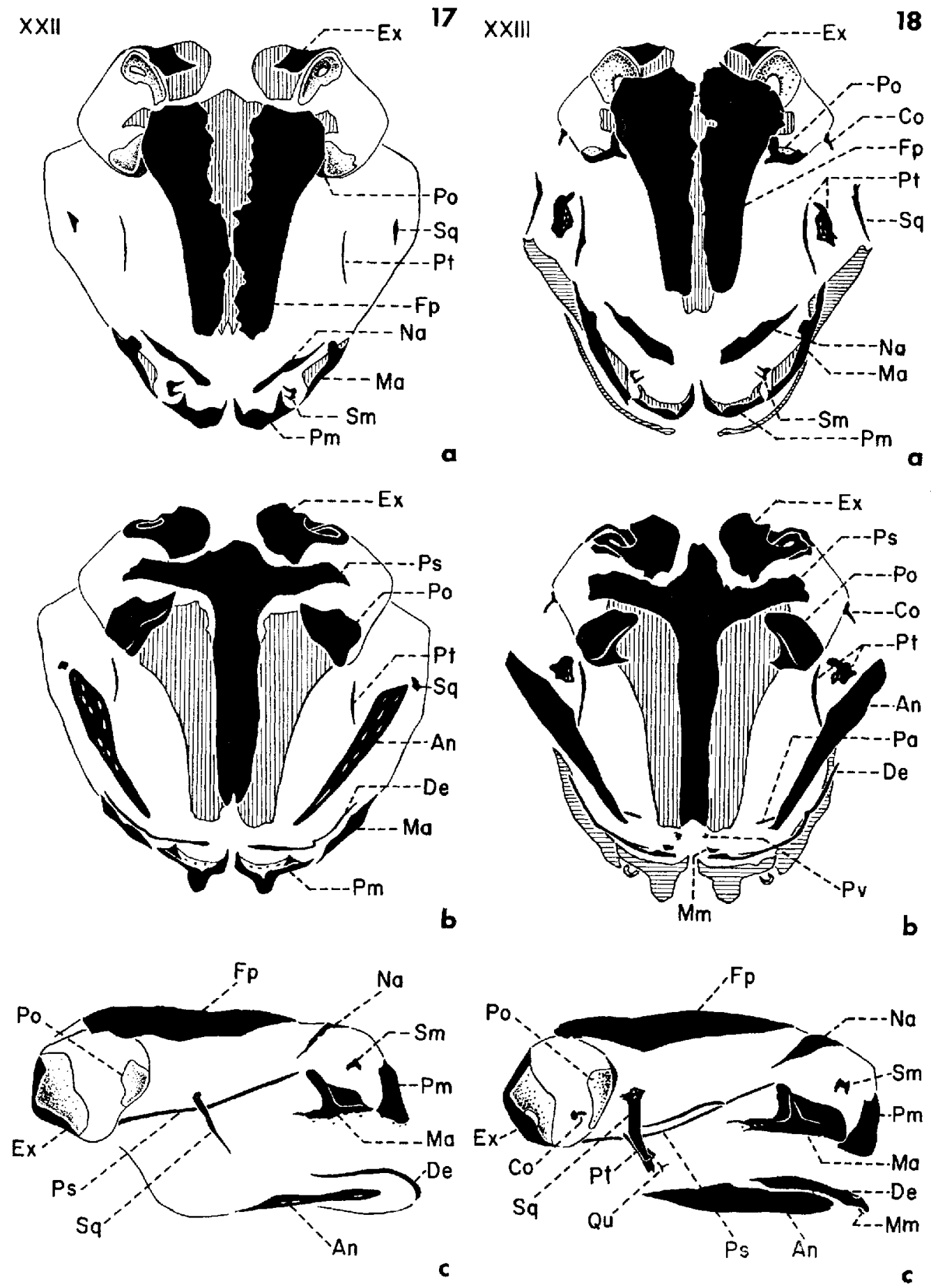


\section{PLATE 8}

EXPLANATION OF FIGURES

Photographs of dorsal (a), ventral (b) and lateral (c) views of alizarin-stained skulls showing bones ossifying at metamorphic stages XXIV and XXV. Explanatory drawings are in plate 9.

19 Stage XXIV. $\times 5$.

20 Stage XXV. $\times 5$. 

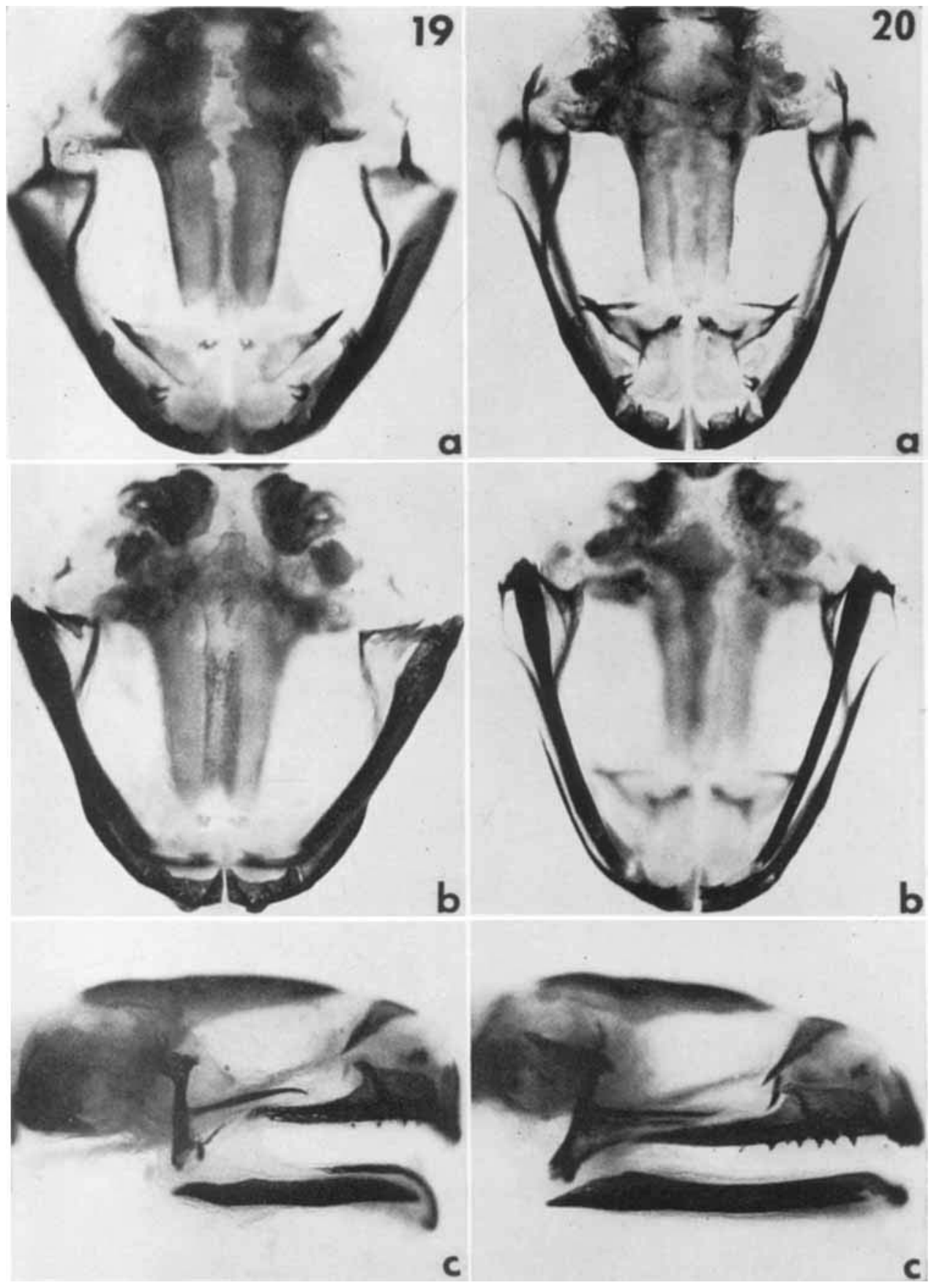
PLATE 9

EXPLANATION OF FIGURES

Drawings of dorsal (a), ventral (b) and lateral (c) views of alizarinstained skulls showing bones ossifying at metamorphic stages XXIV and XXY. Drawings based on photographs in plate 8 .

21 Stage XXIV, Bones present: An, Co, De, Ex, Fp, Va, Mm, Na, Pa, Pm, Po, Ps, Pt, Pv, Qu, Sm, Sq

22 Stage XXV. Bones present: An, Co, De, Ex, Fp, Ma, Mm, Na, Pa, Pm, Po, Ps, Pt, Pv, Qu, Sm, Sq. 

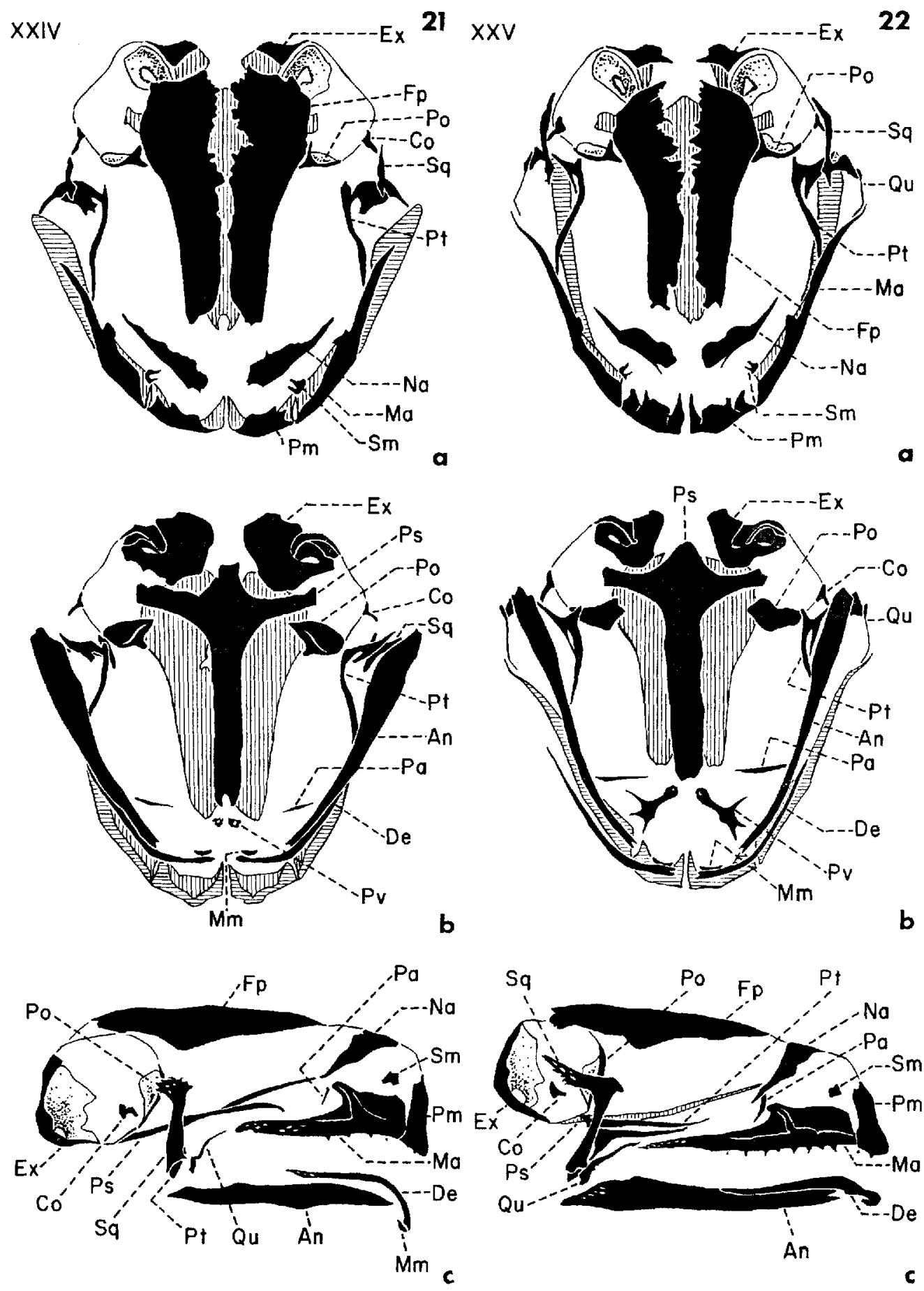